\title{
Management of Pink Bollworm Pectinophora gossypiella (Saunders) Using Mating Disruption Pheromone (PB Rope L) in Cotton
}

\section{Roop Singh Meena ${ }^{1 *}$, Pardeep Kumar ${ }^{1}$, Bharat Lal Meena ${ }^{2}$ and Bhagwan Singh Meena ${ }^{1}$}

${ }^{1}$ Agricultural Research Station, Sriganganagar, Sawmi Keshwananad Rajasthan Agricultural University, Bikaner, Rajasthan, India

${ }^{2}$ Krishi Vigyan Kendra, Sawai Madhopur, Agriculture University, Kota, Rajasthan, India

*Corresponding Author: Roop Singh Meena, Agricultural Research Station, Sriganganagar, Sawmi Keshwananad Rajasthan Agricultural University, Bikaner, Rajasthan, India.
Received: January 02, 2021

Published: February 15, 2021

(C) All rights are reserved by Roop Singh

Meena., et al.

\begin{abstract}
The efficacy of mating disruption pheromone (PB Rope L) was evaluated against pink bollworm Pectinophora gossypiella (Saunders) to monitoring pheromone traps catches as well as by sampling of bolls to record larval population and damage levels in cotton fields during Kharif 2016 and 2017, in north zone of India. This experiment was conducted in large plot in 10.0 ha and 4.0 ha area reserved as control. The main field $\mathrm{T}_{1}$ and $\mathrm{T}_{2}$ divided into two subplots $\mathrm{T}_{1} \mathrm{~A}$ and $\mathrm{T}_{1} \mathrm{~B}, \mathrm{~T}_{2} \mathrm{C}$ and $\mathrm{T}_{2} \mathrm{D}$ of equal size. In each of the subplots, six quadrates approximately 10x10 meter in the center at equal distance were marked. The treated fields were compared with control fields, three to four insecticides sprays in $\mathrm{T}_{1} \mathrm{~A}$ and $\mathrm{T}_{1} \mathrm{~B}$, whereas 6 spray in $\mathrm{T}_{2} \mathrm{C}$ and 9 sprays were applied in $\mathrm{T}_{2} \mathrm{D}$. The dispensers reduced pink bollworm catches in pheromone trap and reduced larval population and crop damage. Results showed that moth catches were highly suppressed in the treated fields by installation of the dispensers @ 685 PB Rope L at 50 days after crop sowing. Damage percentage was significantly reduced in treated fields as compared to control fields; Significant difference was observed in average seed cotton yield/ha. This study recommends the use of single application of pheromone dispenser at 50 days after crop sowing. These Rope were sufficient to maintain the moth catches and percent green boll infestation at the lowest level as compared to untreated field.
\end{abstract}

Keywords: Cotton; PB Rope L; Pink Bollworm; Mating Disruption

\section{Introduction}

Cotton is an important fiber crop of global significance, which is, cultivated in tropical and sub-tropical region of more than seventy countries in the world. It is the major cash crop of India and account 65 per cent of the fiber used in textile industry. Cotton plays a key role in the national economy in terms of both employment generation and foreign exchange earnings. This crop impacts the lives of an estimated 60 million people in India, including farmers who cultivate the crop and a legion of workers involved in the cotton industry from processing to trading. India has largest acreage (105 lakh ha) under cotton at global level and has the productivity of $568 \mathrm{~kg}$ Lint/ha and rank first in production (351 lakh bales) after 
China during 2016-17. Cotton has been associated with as many as 1,326 insect pest species [10], however, the most serious one is mainly due to the damage of green bolls which caused by the cotton bollworms. Among them, the most important is pink bollworm, Pectinophora gossypiella (Saunders) (Lepidoptera: Gelechiidae) [3]. The pest attacks fruiting portion, flower and green bolls reducing both quality and quantity of harvested seed cotton by consign about $20.21 \%$ losses in 1979 [1], similarly, about 50.47 and 36.63 per cent yield losses were reported due to pink bollworm in Gossypium hirsutum and G. arborium, respectively in Punjab [8]. However, in Gujarat and southern part (Telangana and Andhra Pradesh) of India pink bollworm infestation was noticed with increasing trend on non-Bt and Bt cotton in last decade. Manjunatha., et al. [18] reported lower percent of rosette flower $(0.01-1.57 \%)$ in different Bt hybrids, survival of pink bollworm larvae, and damage ranged 0 - 80 percent reported on BG-II Bt hybrids in some districts of Gujarat [13].

In cotton the insecticide usage is very high accounting almost 22.50 per cent of total insecticide consumed worldwide. The major control method of cotton pests, especially the bollworm, is still depend upon chemical pesticides [19]. Indiscriminate use of pesticides often results creating new problem of pest resistance, new pest emergence and poor control due to their drastic effect on natural enemies, beside highly expensive and hazardous to human health and environment [5].

During last two decade developing alternate non-chemical technique, effective and ecofriendly to suppress pest incidence in cotton are essentially needed. Mating disruption technology was introduced to successfully manage the pink bollworm infestation by some advanced countries. The gossyplure has been extensively used for management of pink bollworm [12]. The efficacy of mating disruption by reducing of moth catching and percent boll damage in cotton has been confirmed in Greece with the application of PB Rope dispensers [16,17]. Different formulations of mating disruption pheromone introduced and evaluate and some of them were much improved in efficacy as compared to early formulations. Among them, shin-Estsu's formulation PB Rope L gave excellent and stable performance with longevity. PB Rope L (Pink Bollworm Rope Long) is a sex pheromone dispenser of pink bollworm contains ZZ/ZE-7, 11-hexadecadienyl acetate in two plastic tube (2 - 3 $\mathrm{mm}$ diameter and $20 \mathrm{~cm}$ long) which are attached together by both ends. Pheromone is released gradually in the environment through the wall of tube. It has better future in integrated management of cotton bollworm, particularly to pink bollworm in view of numerous advantages. This technology not only manage pink bollworm infestation as well as enhance the natural enemies' activities in cotton agro-ecosystem as a result, secondary pest also be suppressed.

\section{Aim of the Study}

The present study was conducted to evaluate the efficacy of BP Rope L against pink bollworm with large-scale field trial at Agricultural Research Station, Sriganganagar, Rajasthan, India during, Kharif 2016 and 2017.

\section{Materials and Methods}

Study location: This study was conducted in 14.0 hectare area, at Agricultural Research Station, Sriganganagar (Rajasthan) India, cultivated with American cotton variety MR-786 non-Bt, sown on $29^{\text {th }}$ and $11^{\text {th }}$ May in the both seasons $2016-17$ and 2017-18, respectively.

Treatment details: In each year, crop was raised in two isolated fields, having isolation distance of $1.0 \mathrm{~km}$. The main field T1 was implemented with PB Rope L, in 10.0 ha and T2 about 4.0 ha area for control field. The main plots were divided into two subplots $\mathrm{T}_{1} \mathrm{~A}$ and $\mathrm{T}_{1} \mathrm{~B}, \mathrm{~T}_{2} \mathrm{C}$ and $\mathrm{T}_{2} \mathrm{D}$ of equal size (Table 1 ).

\begin{tabular}{|l|c|}
\hline \multicolumn{1}{|c|}{ Main plot } & \multicolumn{1}{c|}{ Sub plot } \\
\hline \multirow{2}{*}{$\begin{array}{l}\text { PB Rope } \mathrm{L} \\
\left(\mathrm{T}_{1}\right)\end{array}$} & $\begin{array}{c}\mathrm{T}_{1} \mathrm{~A}: \text { PB Rope } \mathrm{L}+\text { recommended molecule } \\
\text { spray for sucking pests }\end{array}$ \\
\cline { 2 - 2 } & $\begin{array}{c}\mathrm{T}_{1} \mathrm{~B}: \text { PB Rope } \mathrm{L}+\text { Recommended molecule } \\
\text { spray for sucking pests and need based spray } \\
\text { for bollworms }\end{array}$ \\
\hline \multirow{3}{*}{ Control $\left(\mathrm{T}_{2}\right)$} & $\begin{array}{c}\mathrm{T}_{2} \mathrm{C}: \text { Recommended molecule spray for } \\
\text { sucking pests }\end{array}$ \\
\cline { 2 - 2 } & $\begin{array}{c}\mathrm{T}_{2} \mathrm{D} \text { : FSS to control any pests means current } \\
\text { farmers practice to control bollworms as well } \\
\text { as sucking pest }\end{array}$ \\
\hline
\end{tabular}

Table 1: Treatment details.

Each subplot was demarcated into six quadrates approximately $10 \times 10 \mathrm{~m}$ in the center at equal distance for the sampling. Each quadrate was designated as one replication. All subplots were raised with uniform agronomic practices. Insecticides sprays were 
applied to all the subplots as per the experiment requirement (ETL basis).

Pheromone traps were installed for Pectinophora gossypiella moth trapping in each quadrate on 9 July and 28 May in 2016 and 2017 , respectively. The traps were fixed one foot above crop canopy and the lure changed at 15 days interval throughout the crop duration. Moth catches were recorded until harvest at twice in a week (Monday and Friday) from each treatment throughout the experimental period.

Details of the PB Rope $L$ and its application: In $T_{1} A$ and $T_{1} B$ PB Rope L was fixed on 20 and 8 July in 2016 and 2017, respectively, using 685 dispensers/ha. The dispensers were made from ShinEtsu Chemical Co. Ltd., Tokyo, Japan and likely to be introduced in India by PI Industries Ltd., Gurgaon. The length of each dispenser was $20 \mathrm{~cm}$ and $2.5 \mathrm{~mm}$ diameter contain $78 \mathrm{mg}$ (AI) gossyplure (ZZ/ZE-7, 11-hexadecadienyl acetate). Dispensers were twisted by hand around the main stem above first or second pair of true leaves at the first pin square stage. The greater number of ropes at boarder towards windward side and lesser number PB Rope on opposite side while covering boundary of main plot. Single time application of PB Rope L was made during the cropping seasons.

Observation recorded: In addition, most preferred plant part i.e. green and open bolls were collected and examined carefully for the presence of pink bollworm larvae and associated damage viz. green boll, open boll, locule, seed and seed cotton respectively. Sampling started on 21 August in 2016 and 2017, respectively, and sample were taken at weekly interval from five spots, 20 samples were randomly collected from each quadrate per treatment.

The effect of PB Rope dispenser in reducing pink bollworm population were investigated by comparing moth catches in the treated and their respective control fields. The effect of the insecticides spray for sucking pest and sucking pests + bollworm on the efficacy of mating disruption was examined by comparing moth catches between the treated fields $\mathrm{T}_{1} \mathrm{~A}$ and $\mathrm{T}_{1} \mathrm{~B}$ and control fields $\mathrm{T}_{2} \mathrm{C}$ and $\mathrm{T}_{2} \mathrm{D}$. Damage levels were compared between treated and control fields. The effect of spray for sucking pest and sucking pests + bollworm on efficacy of mating disruption was examined by comparing the percentage damage between the treated field $\mathrm{T}_{1} \mathrm{~A}$ and $\mathrm{T}_{1} \mathrm{~B}$, control fields $\mathrm{T}_{2} \mathrm{C}$ and $\mathrm{T}_{2} \mathrm{D}$, respectively. Data were analyzed by one-way ANOVA and data were arc sine or square root transformed before analysis. Mating disruption (\%) was estimated using the formula: \% Disruption $=$ Control plot moth catches- Treated plot moth catches/Control plot moth Catches x 100 [7].

\section{Results}

Population monitoring

The main objective of the study was to estimate the mating disruption measured in terms of number of moths caught in pheromone traps or the damage to the green and open bolls. In both years, the number of moths caught in the traps were less in treated plots as compared to the control treatment. Mating disruption reached 77.42, 81.09 and 98.27, 99.46 per cent in the fields T1A and $\mathrm{T} 1 \mathrm{~B}$, respectively during both the years.

In 2016, in the field treated with recommended molecule for sucking pests (T2C), trap catches were higher in last September, in early and last October and November (Figure 1a) and obtained its peak on October 10 (86.33), 30 (81.17) and November 6 (96.17 moths/trap/week), respectively. In the field treated with FSS to control any pests means current farmers practice to control bollworms as well as sucking pest (T2D), trap catches were higher in last September, in mid and last October and early and mid-November and peaked on October 10, 30 and November 6, 19 (94.33, 75.50, 87.67 and 80.33 moths/trap/week, respectively). Trap catches in the treated fields recorded below 25 moths/trap/week. The number of trap catches in the treated fields (T1A: PB Rope L+ recommended molecule spray for sucking pests, $\mathrm{T}_{1} \mathrm{~B}$ : PB Rope L+ Recommended molecule spray for sucking pests and need based spray for bollworms) were found significantly less than that in the respective checks fields (T2C, T2D) $\left(\mathrm{F}_{1,37}=12.5663, \mathrm{P}=0.0011\right.$ and $\mathrm{F}_{\mathrm{t}}=4.1132$ and $\mathrm{F}_{1,37}=11.8224, \mathrm{P}=0.0015$ and $\mathrm{F}_{\mathrm{t}}=4.1132$ ) (Figure 1a).

Similarly, in 2017, in the field treated with recommended molecule for sucking pests (T2C), trap catches were higher in last August, in early and last October and November (Figure 1b) and peaked on October 9, 24 and November 4, 11 reaching 32.00, $32.17,67.50$ and 80.33 moths/trap/week, respectively. In the field treated with FSS to control any pests means current farmers practice to control bollworms as well as sucking pest (T2D), trap catches were high in mid-September, last October and early November and peaked on October 24 and November 4, 11 (51.83, 69.83 and 66.50 moths/trap/week, respectively). Trap catches in the treated 


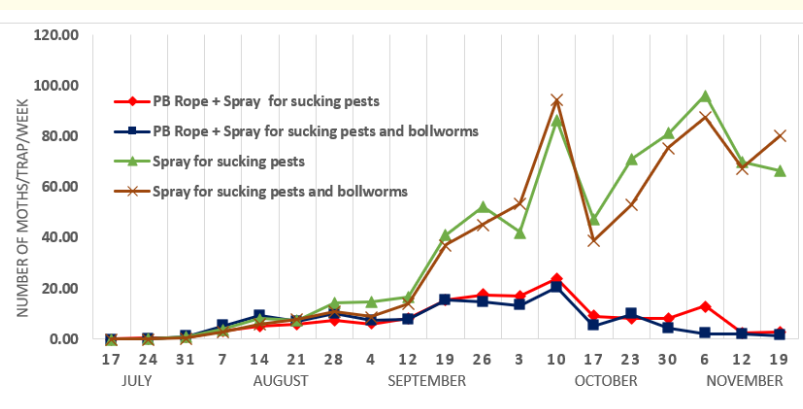

Figure 1a: Week wise moth catches of pink bollworm (Pectinophora gossypiella) kharif-2016.

fields were observed below 2.33 moths/trap/week. The number of trap catches in the treated fields (T1A: PB Rope L+ recommended molecule spray for sucking pests, $\mathrm{T}_{1} \mathrm{~B}$ : PB Rope L+ Recommended molecule spray for sucking pests and need based spray for bollworms) were found significantly less than that in the respective checks fields (T2C, T2D) $\left(\mathrm{F}_{1,37}=31.2095, \mathrm{P}=0.0001\right.$ and $\mathrm{F}_{\mathrm{t}}=4.1132$ and $F_{1,37}=40.033, P=0.0001$ and $F_{t}=4.1132$ ) (Figure $1 \mathrm{~b}$ ).

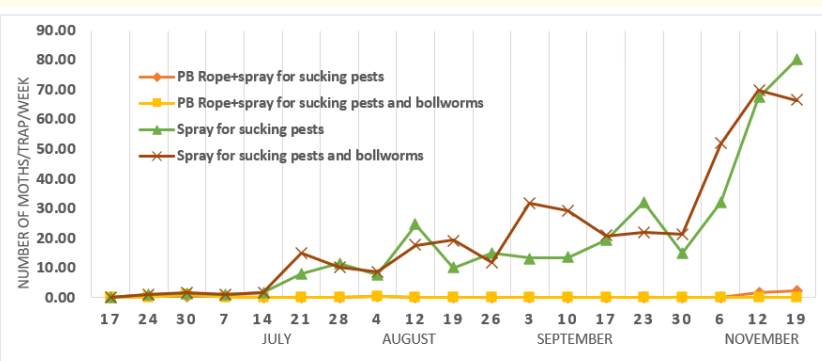

Figure 1b: Week wise moth catches of pink bollworm (Pectinophora gossypiella) kharif-2017.

\section{Larval population}

In 2016, in the field treated with recommended molecule for sucking pests (T2C), larval population crossed ETL in last September, in October and November (Figure 2a) and peak occurrence recorded in October and mid-November, ranging 3.33 - 4.17 larvae/20 bolls, respectively. In the field treated with FSS to control any pests means current farmers practice to control bollworms as well as sucking pest (T2D), larval population were higher in October and mid-November and peaked activity reported in October and early November, ranging from 3.00 - 4.17 larvae/20 bolls, respectively. Larval population in the treated fields were reported below 1.83 larvae/20 bolls. The number of larvae in the treated fields (T1A: PB Rope L+ recommended molecule spray for sucking pests, $\mathrm{T}_{1} \mathrm{~B}$ : PB Rope L+ Recommended molecule spray for sucking pests and need based spray for bollworms) were found significantly less than that in the respective checks fields (T2C, T2D) $\left(\mathrm{F}_{1,37}=4.2963\right.$, $\mathrm{P}=0.0482$ and $\mathrm{F}_{\mathrm{t}}=4.2252$ and $\mathrm{F}_{1,37}=4.7737, \mathrm{P}=0.0381$ and $\mathrm{F}_{\mathrm{t}}=$ 4.2252) (Figure 2a).

In 2017, in the field treated with recommended molecule for sucking pests (T2C), larval population crossed ETL in mid-September, in October and November (Figure 2a) and peak occurrence found in October and mid-November, ranging 3.33 - 4.67 larvae/20 bolls, respectively. In the field treated with FSS to control any pests means current farmers practice to control bollworms as well as sucking pest (T2D), larval population were higher in mid-September, in October and mid-November and peaked activity reported in October and early November, ranging from 3.17 - 4.83 larvae/20 bolls, respectively. Larval population in the treated fields were reported below 1.67 larvae/20 bolls. The number of larvae in the treated fields (T1A: PB Rope L+ recommended molecule spray for sucking pests, $\mathrm{T}_{1} \mathrm{~B}$ : PB Rope $\mathrm{L}+$ Recommended molecule spray for sucking pests and need based spray for bollworms) were found significantly less than that in the respective checks fields (T2C, T2D) $\left(\mathrm{F}_{1,37}=9.8406, \mathrm{P}=0.0042\right.$ and $\mathrm{F}_{\mathrm{t}}=4.2252$ and $\mathrm{F}_{1,37}=11.1640, \mathrm{P}=$ 0.0025 and $F_{t}=4.2252$ ) (Figure $2 b$ ).

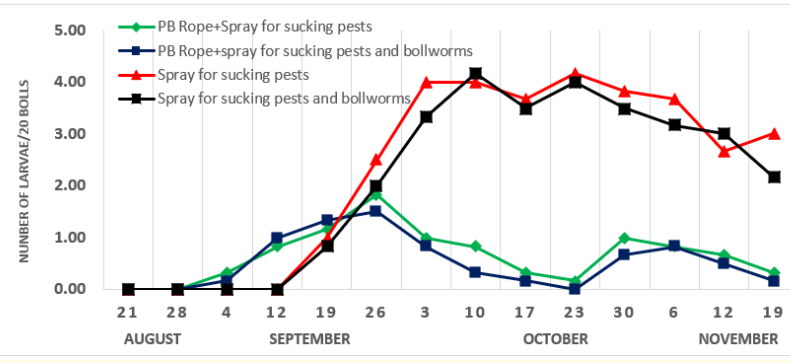

Figure 2a: Larval population of pink bollworm (Pectinophora gossypiella) in green bolls, Kharif-2016. 


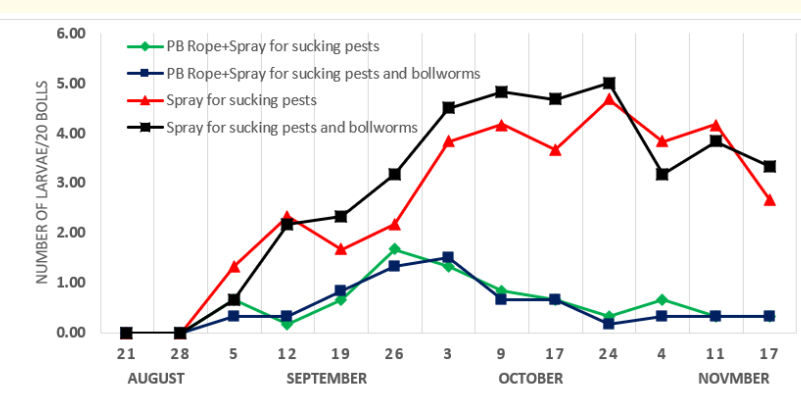

Figure 2b: Larval population of pink bollworm (Pectinophora gossypiella) in green bolls, Kharif- 2017.

\section{Boll damage estimation}

In both years, the damage (\%) in the insecticide treated control fields T2C and T2D were significantly higher than the respective PB Rope + insecticides treated fields T1A and T1B $\left(\mathrm{F}_{1,37}=5.9946, \mathrm{P}=\right.$ 0.0248 and $F_{t}=4.2252$ and $F_{1,37}=8.3641, P=0.0097$ and $F_{t}=4.2252$, $\mathrm{F}_{1,37}=36.4975, \mathrm{P}=0.0001$ and $\mathrm{F}_{\mathrm{t}}=4.2252$ and $\mathrm{F}_{1,37}=36.0652, \mathrm{P}=$ 0.0001 and $F_{t}=4.2252$, respectively).

In 2016, damage (\%) in bolls in $\mathrm{T}_{1} \mathrm{~A}$ (PB Rope $\mathrm{L}+$ recommended molecule spray for sucking pests), $\mathrm{T}_{1} \mathrm{~B}$ (PB Rope $\mathrm{L}+$ Recommended molecule spray for sucking pests and need based spray for bollworms) were lower and had peak on $17^{\text {th }}$ October (14.33\%) and $29^{\text {th }}$ September (12.33\% boll damage), respectively (Figure 3a). In control field $\mathrm{T}_{2} \mathrm{C}$ (Recommended molecule for sucking pests), $\mathrm{T}_{2} \mathrm{D}$ (FSS to control any pests means current farmers practice to control bollworms as well as sucking pest) percentage of damage to bolls recorded relatively higher (10.33 - 30.67 and 11.00 - $28.00 \%$ ) from last September to early November and peak was observed on $10^{\text {th }}$ (30.67\%) and $23^{\text {rd }}$ October (28.00\% boll damage), respectively.

In 2017, relatively low percentage damage was recorded in $\mathrm{T}_{1} \mathrm{~A}$ (PB Rope L+ recommended molecule spray for sucking pests) and $\mathrm{T}_{1} \mathrm{~B}$ (PB Rope L+ Recommended molecule spray for sucking and need based spray for bollworms) with peak recorded on 9 October, 15.83 and $15.00 \%$, respectively (Figure $3 \mathrm{~b}$ ). Percent damage in respective control field $\mathrm{T}_{2} \mathrm{C}$ (Recommended molecule for sucking pests), $\mathrm{T}_{2} \mathrm{D}$ (FSS to control any pests means current farmers practice to control bollworms as well as sucking pest) was relatively

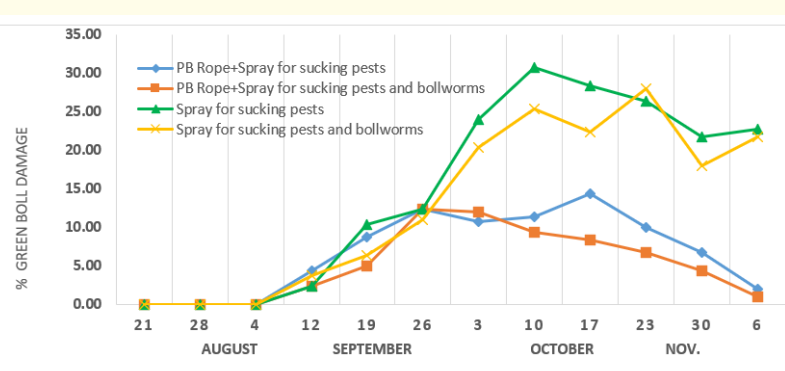

Figure 3a: Green boll damage due to pink bollworm (Pectinophora gossypiella), Kharif-2016. higher ranging 13.33 - 66.67 and 10.83 - 78.33\% from mid-September to mid-November and peak recorded on $9^{\text {th }}$ October, 66.67 and $78.33 \%$, respectively. Relatively higher yield was reported from PB Rope treated fields $\left(\mathrm{T}_{1} \mathrm{~A}\right.$ and $\left.\mathrm{T}_{1} \mathrm{~B}\right)$ as compared to control fields $\left(\mathrm{T}_{2} \mathrm{C}\right.$ and $\left.\mathrm{T}_{2} \mathrm{D}\right)$ (Table 2).

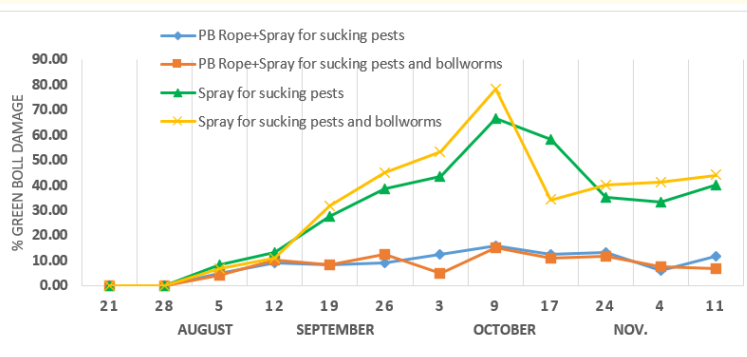

Figure 3b: Green boll damage due to Pink bollworm (Pectinophora gossypiella), Kharif-2017.

\section{Discussion}

The studies conducted revealed during both years, the trend of moth catches was similar, whereas moth catches were comparatively higher in the first year (Figure 1). The findings of the study also recorded higher moth catches in last September, October and November, with peak during October and November in both years. Pink boll worm population density was higher in August and obtained its peak during September in Egypt and Pakistan [6,24] but in India, higher pink bollworm population was recorded in Novem- 


\begin{tabular}{|c|c|c|c|c|c|c|c|c|}
\hline \multirow{3}{*}{$\begin{array}{c}\text { No. of } \\
\text { picking }\end{array}$} & \multicolumn{8}{|c|}{ Yield (q/ha) } \\
\hline & \multicolumn{4}{|c|}{2016} & \multicolumn{4}{|c|}{2017} \\
\hline & $\mathbf{T}_{1} \mathbf{A}$ & $\mathbf{T}_{1} \mathbf{B}$ & $\mathrm{T}_{2} \mathrm{C}$ & $\mathbf{T}_{2} \mathbf{D}$ & $T_{1} A$ & $\mathbf{T}_{1} \mathbf{B}$ & $\mathrm{T}_{2} \mathrm{C}$ & $T_{2} D$ \\
\hline $1^{\text {st }}$ & 4.40 & 4.94 & 3.65 & 3.83 & 6.62 & 7.80 & 5.08 & 4.44 \\
\hline $2^{\text {nd }}$ & 11.08 & 12.20 & 8.30 & 9.05 & 14.59 & 15.47 & 11.58 & 10.73 \\
\hline $3^{\text {rd }}$ & 6.60 & 6.67 & 5.13 & 5.06 & 8.36 & 8.13 & 6.63 & 5.99 \\
\hline Total & 22.08 & 23.81 & 17.08 & 17.94 & 29.57 & 31.40 & 23.29 & 21.16 \\
\hline $\begin{array}{l}\text { F cal. } \\
\text { Value }\end{array}$ & \multicolumn{4}{|c|}{0.3574} & \multicolumn{4}{|c|}{0.5471} \\
\hline P value & \multicolumn{4}{|c|}{0.7849} & \multicolumn{4}{|c|}{0.6639} \\
\hline $\begin{array}{l}\text { F tab. } \\
\text { Value }\end{array}$ & \multicolumn{4}{|c|}{4.0662} & \multicolumn{4}{|c|}{4.0662} \\
\hline
\end{tabular}

Table 2: Impact of PB Rope L on seed cotton yield.

ber (45 ${ }^{\text {th }}$ SMW) [25], whereas two peaks (mid-April to mid-May and mid-October to December) of the pest was observed in Paki$\operatorname{stan}[2]$.

The main objective of the study was to disturb the orientation of male and significantly lower catches of Pectinophora gossypiella moth in pheromone traps in treated fields in 2016 and 2017 compared to control fields (Figure 1), indicted that mating disrupting pheromone application was very effective in reducing population of Pectinophora gossypiella in cotton fields, only three to four insecticides sprays in treated fields in comparison to seven and nine spray in control were applied. The lesser number of moths catches in PB Rope treated fields were reported by Lykouressis., et al. [16], Lykouressis., et al. [17] and Patil., et al. [22]. Very low number moth catches in PB Rope treated plots indicated the effectiveness of pheromone for male disorientation in the field, which resulted low mating success, reduced oviposition rate and larval development in the crop.

The results indicated that fixing of PB Rope in the fields, resulted into 75 to $100 \%$ mating disruption in case of pink bollworm during both years significant reduction in the percentage of green boll damage and number of larvae till harvesting. The damage (\%) and larval infestation in control field was much higher than the treated fields and its picks was observed in October. Earlier studies carried out by Athanassiou., et al. [4], Lykouressis., et al. [16], Lykouressis., et al. [17], Patil., et al. [23] and Mohamed., et al. [20], also reported that moth catches, larval population and damage caused by pink boll worm was much lower in the treated field as compared to control fields. It is a positive indicator of effectiveness of pheromone application in the form of PB Rope and creating disturbance in communication between the male and female, leading to mating disruption. As a result, significantly higher cotton yield was recorded from treated fields as compared to control fields.

The application of pheromone dispenser depends upon the activity of pink bollworm at the respective location our results also indicate that the efficacy of the pheromone dispensers stretched about 120 days after application till the harvesting. Similar results were observed by Flint., et al. [9] where initial emission rate of pheromone decreased linearly during first 50 days after establishment, and was kept at constant level afterward, while half of pheromone was evaporated 60 days after implementation. In addition, Sohi., et al. [26] recorded $1.5 \mathrm{mg}$ pheromone released per dispenser per day, which reduced $0.80 \mathrm{mg}$ per day per dispenser after 90 days of installation. Papa., et al. [21] observed the efficiency of pheromone dispenser and found that the release period from dispenser was 120 days. Similarly, in the central Greece Lykouressis., et al. [17] found that pheromone dispenser significantly commits the mating disruption of Pectinophora gossypiella and effectively prevent the damage, when applied in early season, whereas damage level was not proportionately, reduced in relation to the reduction of trap catches. Sufficient gossyplure for reducing moth catches in the traps was in pheromone dispensers even 90 days in field.

The plots fixed with PB Rope were applied lesser number of insecticidal sprays in comparison to the control. Which eventually helped in conservation of natural enemies regulating the population of other cotton pest like whitefly, jassid and thrips during both the years. This is additional advantage with mating disruption technique in the form of conservation of natural enemies relatively higher number in this area on cotton $[14,15]$. This indirect effect of mating disruption also scores great value within the framework of pest management system in cotton and is one of the main advantages of this method $[6,11]$.

\section{Conclusion}

This study revealed that the effectiveness of pheromone in the form of PB Rope in reducing pink boll worm catches and lowering the damage. This study recommended using single application of 
pheromone dispenser (PB Rope L) at 50 days after crop sowing, plants was sufficient to maintain the moth catches and percent infestation in green boll at the lowest level as compared to untreated fields. Though damage level were not proportionally reduced as compared to the reduction of moth catches, so it is advisable to apply other control measure along with mating disruption pheromone. These results underline the importance of this method in pink bollworm management as part of IPM and conservation of natural enemies and reduction in insecticide load.

\section{Acknowledgement}

Authors are thankful to AICRP cotton and PI Industries Ltd., Gurgaon (India) for providing financial assistance. We are also grateful to Director Research, Sawmi Keshwananad Rajasthan Agricultural University, Bikaner and Zonal Director Research, Agricultural Research Station, Sriganganagar for providing this opportunity and support.

\section{Bibliography}

1. Agarwal RA and Katiyar KN. "An estimate of losses of seed cotton and seed due to bollworms on cotton in India". The Indian Journal of Entomology 41 (1979): 143-148.

2. Ali A., et al. "Influence of weather factors on the trapped population of pink bollworm Pectinophora gossypiella (Saunders) under Multan Agro-ecosysyem". Journal of Entomology and Zoology Studies 04 (2016): 02-06.

3. Amin AA and Gergis MF. "Integrated management approaches, strategies for controlling certain cotton key pests in middle Egypt". Agronomy Research 4 (2006): 121-128.

4. Athanassiou CG., et al. "Evaluation of mating disruption method for the control of pink bollworm Pectinophora gossypiella (Saunders) (Lepidoptera:Gelechiidae) and comparison of this method with insecticidal treatments". IOBC/WPRS Bull 25.9 (2002): 39-50.

5. Atwal AS. "Pests of cotton, Agricultural pests of Indian and South East Asia, Kalyani Publisher, Delhi (1994): 281-294.

6. Crithcley BR., et al. "Control of the pink bollworm Pectinophora gossypiella (Saunders) (Lepidoptera:Gelechiidae), in Egypt by mating disruption using an aerially applied microencapsu- lated pheromone formulation". Bulletin of Entomological Research 73 (1983): 289-299.

7. Crithcley BR., et al. "Integrated use of pink bollworm pheromone formulations and selected conventional insecticides for the control of the cotton pest complex in Pakistan". Bulletin of Entomological Research 81 (1991): 371-378.

8. Dhawan AK., et al. "Quantitative and qualitative losses in cotton due to pink bollworm". Agricultural Research Journal-Indian Journals 24.3 (1987): 433-436.

9. Flint HM., et al. "Pink bollworm (Lepidoptera:Gelechiidae): field testing a new polyethylene tube dispenser for gossyplure". Journal of Economic Entomology 78 (1985): 1431-1436.

10. Hargreaves H. "List of recorded cotton insects of the world". Commonwealth Institute of Entomology, London (1948).

11. Johnson MW., et al. "Whiteflies cause problems for southern California growers". California Agricultue (1982): 38-40.

12. Kehat M., et al. "Effect of density of pheromone sources, Pheromone dosage and population pressure on mating of pink bollworm, Pectinophora gossypiella (Saunders) (Lepidoptera:Gelechiidae)". Bulletin of Entomological Research 89 (1999): 339-345.

13. Kranthi KR. "Pink bollworm strikes Bt cotton". Cotton Stat. News 35 (2015): 01-06.

14. Lykouressis DP and Perdikis DCh. "The phenology and abundance of certain species of orius (Hemiptera:Anthocoridae) that occur in Greece". Israel Journal of Entomology 31 (1997): 47-54.

15. Lykouressis DP., et al. "Cotton aphid and their natural enemies in Voiotia. Proc 7th National Entomological Meeting, Kavala, Greece (1999): 180-187.

16. Lykouressis DP., et al. "Mating disruption of the pink bollworm, Pectinophoragossypiella(Saunders)(Lepidoptera:Gelechiidae) using PB-rope dispensers in cotton fields". Journal of Pest Science 77 (2004): 205-210.

17. Lykouressis DP., et al. "Management of pink bollworm, Pectinophora gossypiella (Saunders) (Lepidoptera:Gelechiidae) by 
mating disruption in cotton fields". Crop Protection 24 (2005): 177-183.

18. Manjunatha R., et al. “Comparative performance of Bt and nonBt cotton against bollworm complex". Karnataka Journal of Agricultural Sciences 22 (2009): 646-647.

19. Mohamed EM., et al. "Effect of adding some chemical additives on increasing the potency and residual effect of Bacillus thuringiensis against the cotton leafworm, Spodoptera littoralis (Lepidoptera:Noctuidae)". Egyptian Journal of Agricultural Research 88 (2010): 103-112.

20. Mohamed HO., et al. "Non-chemical control of the pink bollworm, Pectinophora gossypiella (Saunders) (Lepidoptera:Gelechiidae) in cotton fields at Assuit Governorate, Upper Egypt, I-Using a mating disruption technique". Egyptian Academic Journal of Biological Sciences 88 (2016): 115-124.

21. Papa G., et al. "Efficacy and total release interval of mating disruption pheromone on the control of pink bollworm, Pectinophora gossypiella in cotton under field conditions in Brazil". Proceeding Cotton Conference 2 (2000): 1022-1024.

22. Patil BV., et al. "Management of pink bollworm using PB Rope L mating disruption". In proceeding, International Symposium on Strategies for Sustainable Cotton Production-A-Global Vision, University of Agri. Sci., Dharwad, Karnataka (India) (2004): 172-175.

23. Patil SB., et al. "Management of pink bollworm (Pectinophora gossypiella Saunders) in cotton through mating disruption". Journal of Pest Science 19 (2007): 201-204.

24. Qureshi ZA., et al. "Pheromone trap catches as a means of predicting damage by pink bollworm larvae in cotton". Crop Protection 12 (1993): 597-600.

25. Sarma ASR., et al. "Seasonal dynamics of insect pests of cotton in scare rainfall zone of Andhra Pradesh". Tre. in Bio-sci., 10 (2017): 1349-1353.

26. Sohi AS., et al. "Further studies of mating disruption in pink bollworm, Pectinophora gossypiella (Saunders) using sex pheromone as a component of IPM programme in irrigated cotton fields in Punjab". Pest Management and Economic Zoology 7 (1999): 31-38.

\section{Assets from publication with us}

- Prompt Acknowledgement after receiving the article

- Thorough Double blinded peer review

- Rapid Publication

- Issue of Publication Certificate

- High visibility of your Published work

Website: www.actascientific.com/

Submit Article: www.actascientific.com/submission.php

Email us: editor@actascientific.com

Contact us: +919182824667 